\title{
OPTIMAL HEIGHT OF LAND DEVELOPMENT - AN ECONOMIC PERSPECTIVE
}

\author{
Konrad Żelazowski, PhD \\ Faculty of Economics and Sociology \\ University of Lodz \\ e-mail:kzelazowski@uni.lodz.pl
}

\begin{abstract}
Sky-scrapers are rising in the panorama of big modern cities more and more often, becoming a symbol of dynamic growth and prestige. High-rise development appears to be an answer to the expanding demand for new residential and commercial space as urban land prices continue to go up and the availability of land decreases.

This article aims to identify factors affecting the choice of optimal building height in the context of economic effectiveness. It also presents factors that determine the implementation of high-rise development projects. Given the complexity of this subject matter, emphasis is placed on its economic dimension.
\end{abstract}

Keywords: high-rise buildings, optimal building height.

JEL Classification: R30.

Citation: Żelazowski K., 2015, Optimal Height of Land Development - an Economic Perspective, Real Estate Management and Valuation, Vol. 23, No. 1, pp. 15-23.

DOI: $10.1515 /$ remav-2015-0002

\section{Introduction}

In the early $20^{\text {th }}$ century, high-rise development was a symbol of progress and modernity. Tall office buildings, hotels and residential buildings were an expression of a new style of living and technological potential. Little by little, they were becoming incorporated into the panorama of big cities, particularly in the USA.

However, over a century of experience in high-rise development shows that, as far as users' needs, the creation of property value and spatial order are concerned, this solution may not always be optimal.

Building height is viewed from many perspectives:

- technological, which focuses on the technical and technological possibilities of constructing tall buildings,

- spatial, where the purposefulness of inserting tall buildings into urban fabric is analyzed in terms of spatial order,

- economic, where the rationality of constructing tall structures is assessed against the profitability of such an investment.

Given the complexity of the subject matter, optimal building height in the present article will be considered only in the context of its economic effectiveness. The major factors in the selection of optimal building eight will also be discussed.

\section{High-rise development}

Quite naturally, the primary criterion applied to define high-rise development is the height of buildings. This criterion may vary significantly, however, depending on the surroundings of the 
buildings, particularly the height of adjacent structures. Some of the categories of buildings mentioned in Polish Building Law are as follows (REGULATION OF THE MINISTRY... 2002):

- tall buildings that range in height from over $25 \mathrm{~m}$ to $55 \mathrm{~m}$ (inclusive) above ground level, or residential buildings over 9 to 18 above-ground stories high;

- high-rise buildings that are more than $55 \mathrm{~m}$ above ground level.

The Council on Tall Buildings and Urban Habitat (CTBUH), an international organization doing research in the field of tall development and sustainable urban development, has adopted an informal criterion of $50 \mathrm{~m}$ to identify tall buildings. The Council has also created the category of supertall buildings, i.e. those that are over $300 \mathrm{~m}$ in height.

Regardless of what criterion is applied to identify tall development, statistics point out that the number of tall and supertall buildings is rising steadily and dynamically; a particularly fast growth in their number has been noted over the last 20 years (see Fig. 1).

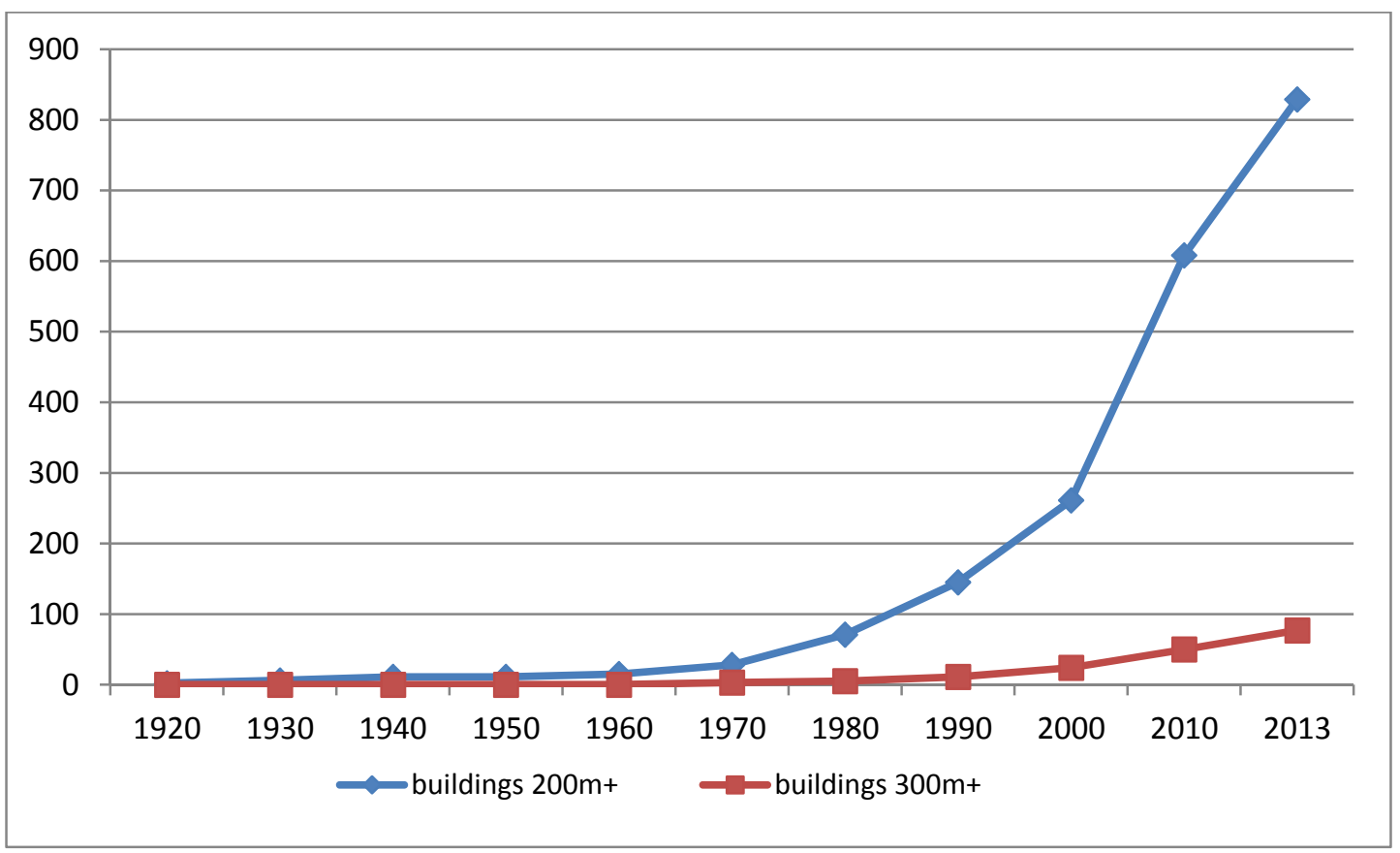

Fig. 1. The number of tall and supertall buildings. Source: developed by the author based on CTBUH data.

Some of the main factors behind the expansion of high development include (FAROUK, 2011):

- population increase in big cities connected with a growth in demand for new residential and commercial space,

- rising prices of land for development,

- restrictions on the territorial expansion of cities,

- high development viewed as a symbol of the progress of civilization and prestige.

In discussions over the future of high development, arguments against it are also brought up. For instance, its critics point to:

- the potential disturbance of the cities' skylines,

- its adverse effect on the surroundings, including overshadowing adjacent properties and disturbance in air flows,

- more traffic problems and more acute shortage of parking places (SERAJ, 1995),

- substantial construction and maintenance costs,

- lower flexibility of management, particularly in periods of economic slowdown.

\section{The economic aspect of building height}

The concept of economically effective building height has many interpretations. Optimal building height can be considered for a specific development project from the perspective of future maintenance costs or in terms of the best height considering the value of the projected property and of adjacent properties. In this article, optimal building height is analyzed from the perspective of a 
developer considering a development project. Accordingly, economic effectiveness will be understood as the effectiveness (profitability) of the projected investment.

To choose building height, developers usually apply the project profitability criterion, i.e. the ratio between development costs and the income the new property is likely to bring in (CHAU, WONG, YAU, CHEUNG, 2007 and KUCHARSKA-STASIAK, 2006).

Development costs are the sum of the price of land (the market value of a piece of land that depends on the permitted use), pre-construction costs (permits, projects, consultations, technical and financial analysis) and actual construction costs:

$$
K_{c}=K_{g}+K_{p}+s \cdot h \cdot k_{b}
$$

where:

$K_{c} \quad$ - total development costs

$K_{g} \quad$ - land price

$K_{p} \quad$ - pre-construction costs

$k_{b} \quad$ - unit construction costs

$s \quad$ - usable area of a floor (to keep the analysis simple, floors are assumed to have similar usable space)

$h \quad$ - the number of floors.

Land price (its market value) depends on a number of supply-side and demand-side factors, such as the availability of land for the projected use, the local market's attractiveness to investors, its growth potential, etc. In seeking optimal building height, these costs are viewed as fixed costs because they are independent of building height. The same goes for pre-construction costs (which in business practice are termed "quasi-fixed costs").

Particularly important in deciding about building height are the costs of the projected development which may vary significantly depending on the height of the building. Clark and Kingston have divided the costs into three categories, taking into account how they change with building height (CLARK, KINGSTON, 1930):

1. Costs that tend to rise in unit terms (per sq. $m$ of usable area). These are mainly:

- Construction costs. The taller the building, the more costly it is to construct a structure ensuring appropriate rigidity of the whole building as well as capable of withstanding heavy loads. The designed shape of the building has a major effect on the construction and its cost.

- The costs of vertical communication. Tall buildings need systems of lifts for fast and easy communication between the floors, as well as extra space for machine rooms.

- The cost of fire safety systems. The systems require special evacuation routes, etc.

- The costs of electrical and plumbing installations, heating and ventilation systems. Tall and supertall buildings need more sophisticated systems that have to meet higher technical standards (LANGDON, WATTS, 2002).

2. Costs that tend to fall in unit terms. The main items in this category are the costs of groundwork, foundations, and roofing.

3. Costs that in unit terms have the character of fixed costs, i.e. are independent of building height. This category of costs includes interior finish costs, etc.

The analysis presented below builds on an assumption that unit construction costs increase with building height. The correctness of this assumption is confirmed by the results of empirical studies. For instance, construction costs analyzed for the British market have been found to be markedly higher for buildings over 20 stories high (see Fig. 2).

The results of studies conducted by P. de Jong and S. van Oss in the Dutch market also show that the unit construction costs rise along with building height. As estimated by these authors, they increase by an average of $8 \%$ every ten floors, with the fast acceleration of costs above the $15^{\text {th }}$ floor. The increase is mainly driven by the costs of construction, lifts and additional services (DE JONG, VAN Oss, 2007).

The source of financial benefits from a development project is the revenue from the sale of the whole property or independent units within it. Literature on the subject does not clearly explain how unit prices change with building height. Studies conducted by D. Butler, J. Siebrits and other 
researchers point out that units located on higher floors involve a price premium. In an analysis of the prices of residential units in tall buildings in London, the premium was estimated at $1.5 \%(1.5 \%$ increase in price with every succeeding floor up). The main factors contributing to the price premium include a more spectacular view (this mainly applies to real properties facing the sea or the ocean), more privacy and security, as well as prestige (BUTLER, SIEBRITS, 2012 and CELKA, 2012).

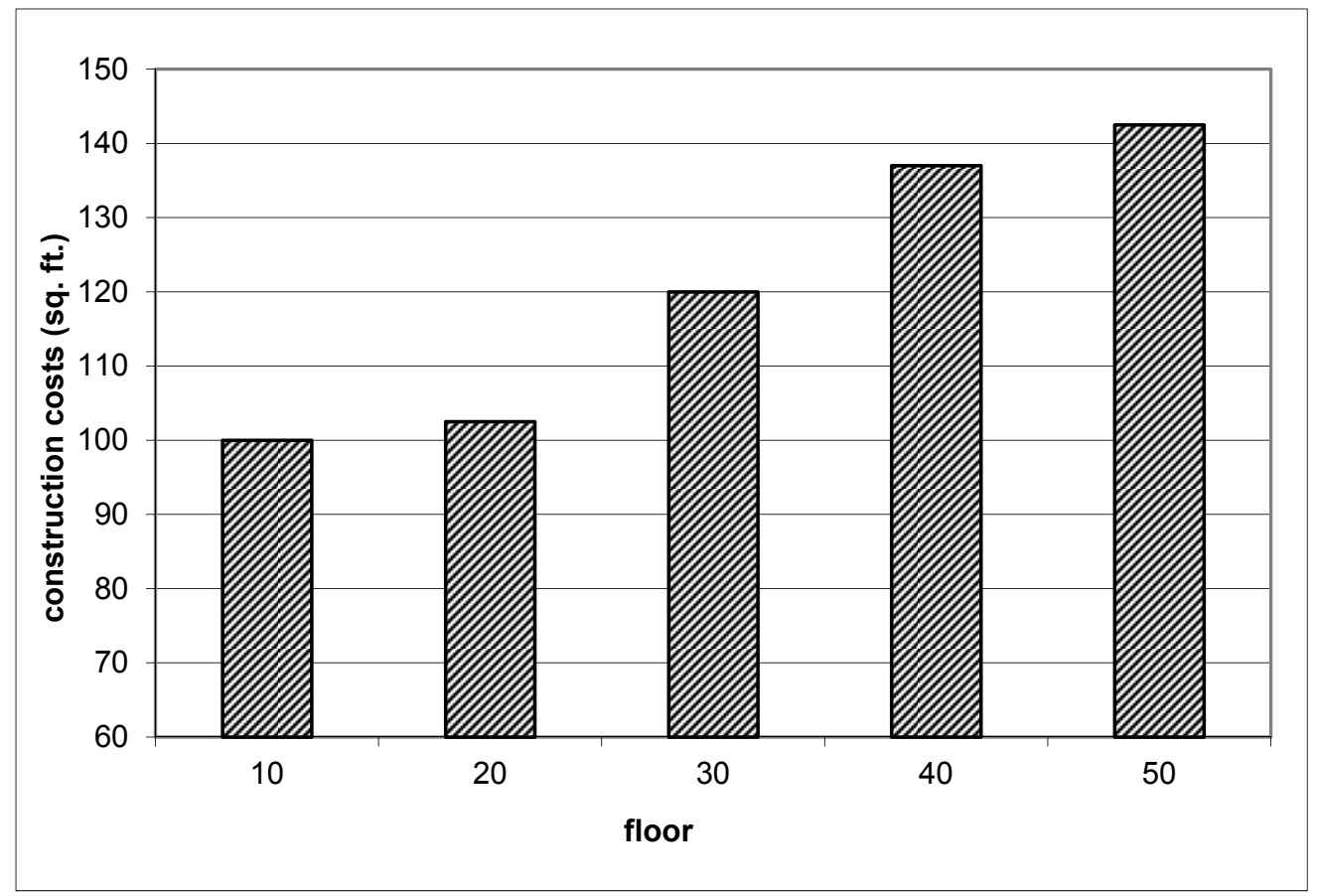

Fig. 2. Percentage change in construction costs in relation to building height (the UK market). Source: KNIGHT FRANK RESEARCH (2007).

Price premiums pertain to both, residential and commercial properties (mainly offices). Studies conducted by Koster, Van Ommeren, and Rietveld in the Dutch market revealed that with building height rising by $10 \mathrm{~m}$, tenants were willing to pay 3\%-4\% more in rent. For buildings taller than $100 \mathrm{~m}$, the price premium was markedly higher.

However, arguments questioning the existence of a price premium can also be found in the available literature. The range of factors that may make buyers less interested in units on higher floors include an unfavorable microclimate (e.g. stronger air turbulences), more time spent on accessing the unit and more complicated access route (causing concerns about whether evacuation in an emergency situation would be fast enough), and high anxiety (CHAU, WONG, YAU, CHEUNG, 2007, ALI, ALKODMANY, 2012 and STACHURA, 2012).

In this article, the height of a building is assumed to have no effect on the unit price of the development. Accordingly, the developer's revenue from the sale of the property is a linear function of the height of the building:

$$
I=p \cdot s \cdot h
$$

where:

I - revenue from the sale of property

$p \quad$ - the price of 1 sq. $\mathrm{m}$ of usable floor area

$s \quad$ - the usable area of one floor

$h \quad$ - the number of floors.

\section{Determination of optimal building height}

To establish what building height will be optimal, the "break-even height" must first be found. How the height is defined depends on the investment profitability criterion adopted. The criterion most frequently found in literature is that of profit maximization, defined as the difference between the property sale revenue and the total costs of development. 
The point where the development cost and revenue curves intersect indicates the minimum height of a building $(X)$. At this point the return on the investment will be zero. The interval within which a development project is profitable ends at $\mathrm{Y}$. For a building that has more stories than $\mathrm{h}_{\max }$, the total development costs will exceed the revenue generated by the project (see Fig. 3).

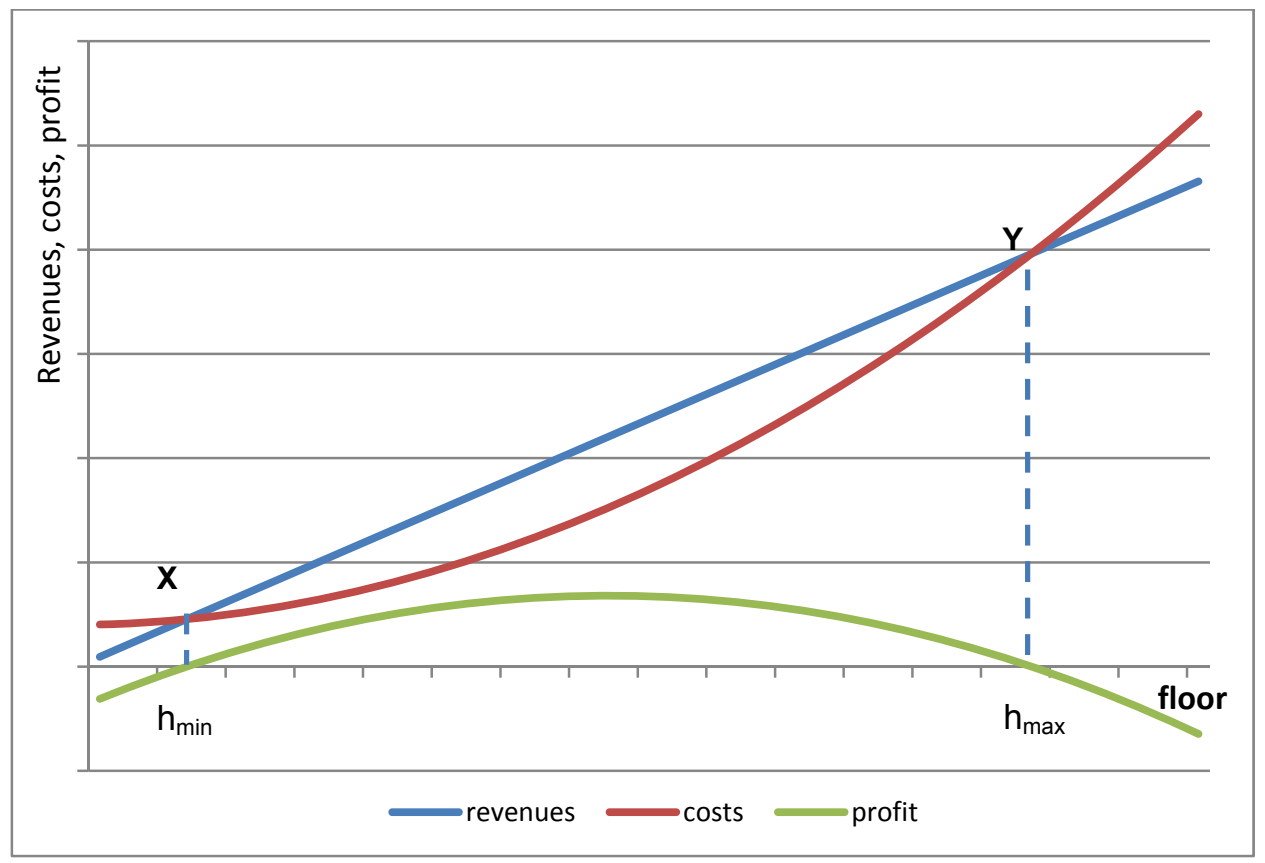

Fig. 3. Minimum and maximum height of development. Source: developed by the author.

In trying to arrive at the minimum building height, it must be remembered that the height is strongly determined by the price of land. This relationship is observable in big cities where the deficit of undeveloped land is particularly clear in central locations attractive to developers. The limited supply of land and high investment demand drive the prices of land property upwards. Higher costs of land, ceteris paribus, force developers to construct buildings with more floors, so that additional revenue from the sale of a greater number of square meters of commercial or residential space make up for the higher price of land (see Fig. 4).

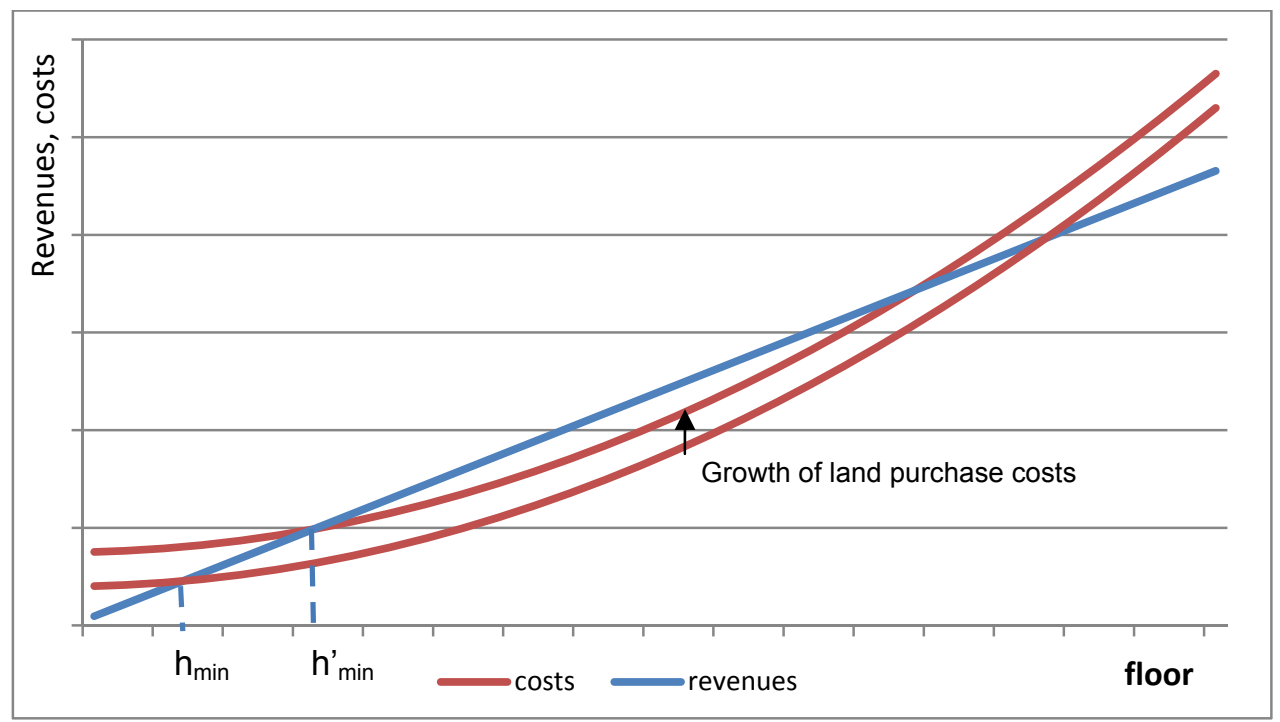

Fig. 4. Change in land purchase costs and its effect on minimum building height. Source: developed by the author.

Therefore, the starting point in the search for the optimal height of development should be the minimal height $\left(h_{\min }\right)$. A rational developer should then try to maximize investment profit by 
considering buildings with more floors than their minimal number and compare revenue achievable from the sale of units situated on each additional floor (marginal revenue - MI) with the costs of having the floor built (marginal costs $-\mathrm{MK}_{\mathrm{c}}$ ). If the revenues outweigh the costs, then the project is profitable and its implementation will increase the total profit from the investment. This decisionmaking algorithm should be run over and over again until the marginal costs and the marginal revenue from the project are equal (see Fig. 5). Therefore, building height that maximizes investment profit meets the following condition:

$$
\begin{aligned}
& M K_{c}=M I \\
& \frac{\partial K_{c}}{\partial h}=\frac{\partial I}{\partial h}
\end{aligned}
$$

where:

$M K_{c}=\frac{\partial K_{c}}{\partial h} \quad$ - marginal costs of development,
$M I=\frac{\partial I}{\partial h} \quad$ - marginal revenue from development.

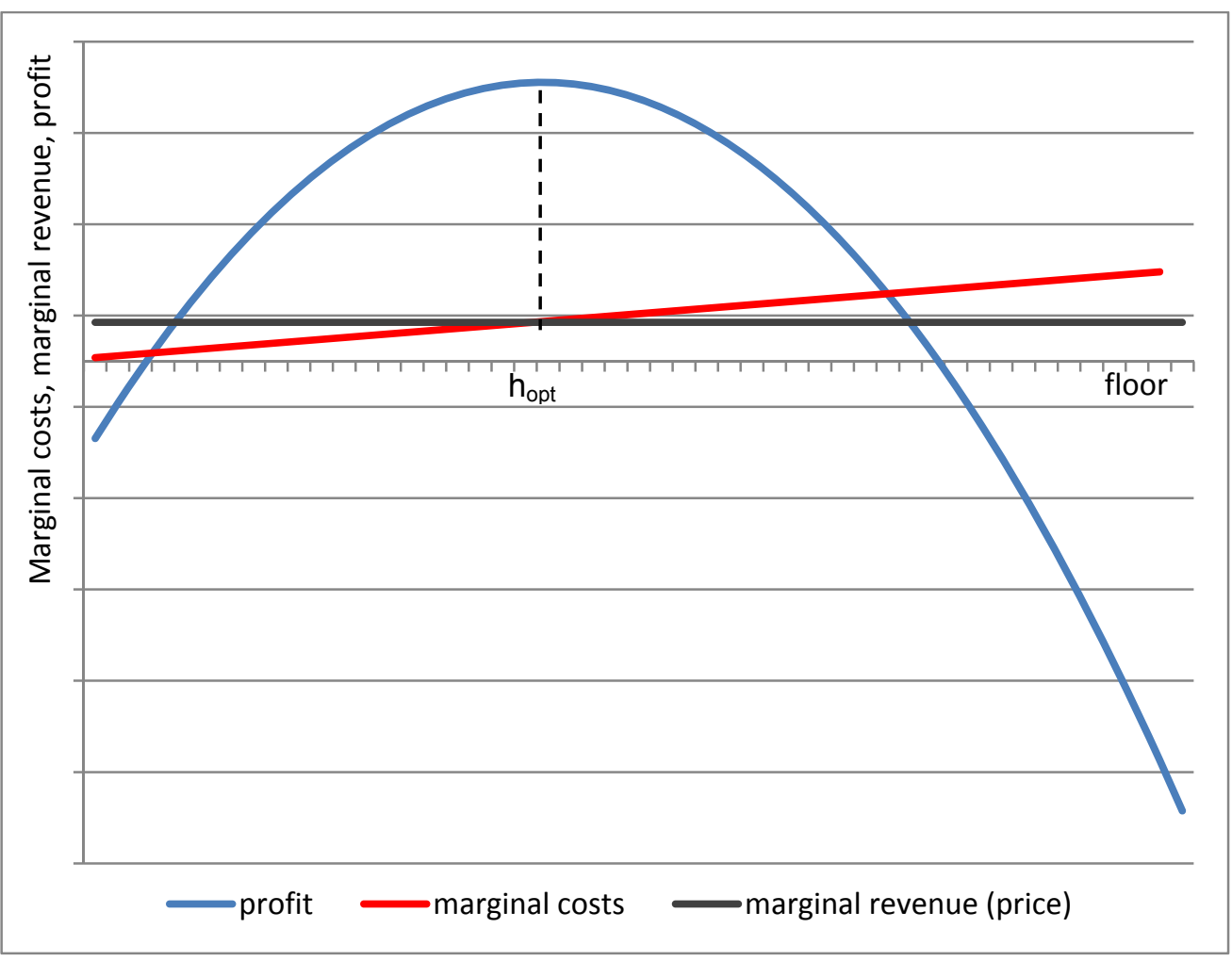

Fig. 5. Development height maximizing investment income. Source: developed by the author.

W. Clark and J. Kingston have proposed a somewhat different approach to establishing optimal building height. According to these researchers, developers can evaluate the effectiveness of their investments with the rate of return (a relative measure), instead of using profit (an absolute measure) (CLARK, KINGSTON, 1930). Under this approach, the optimal height of development is established against the maximum rate of return on the project.

In this particular decision-making situation (the development of landed property), whether or not a development project will be launched, depends on its capacity to yield the expected minimum rate of return. This method of establishing the break-even height and the range of building height values that ensure a given project's minimum profitability is more restrictive than that based on profit maximization.

In the presented case, a developer seeking the optimal development height (i.e. one maximizing the rate of return on the investment) should gradually increase building height until the marginal rate of return is zero (Fig. 6). Not only would a further increase in building height not improve the rate of 
return on the investment, it would, in fact, reduce the value of this measure of profitability. To maximize the rate of return on an investment, building height must fulfil the following condition:

$$
M R R=\frac{\partial R R}{\partial h}=0
$$

where:

$M R R$ - marginal rate of return on the investment

$R R=\frac{I-K_{c}}{K_{c}} \cdot 100 \%$ - rate of return on the investment.

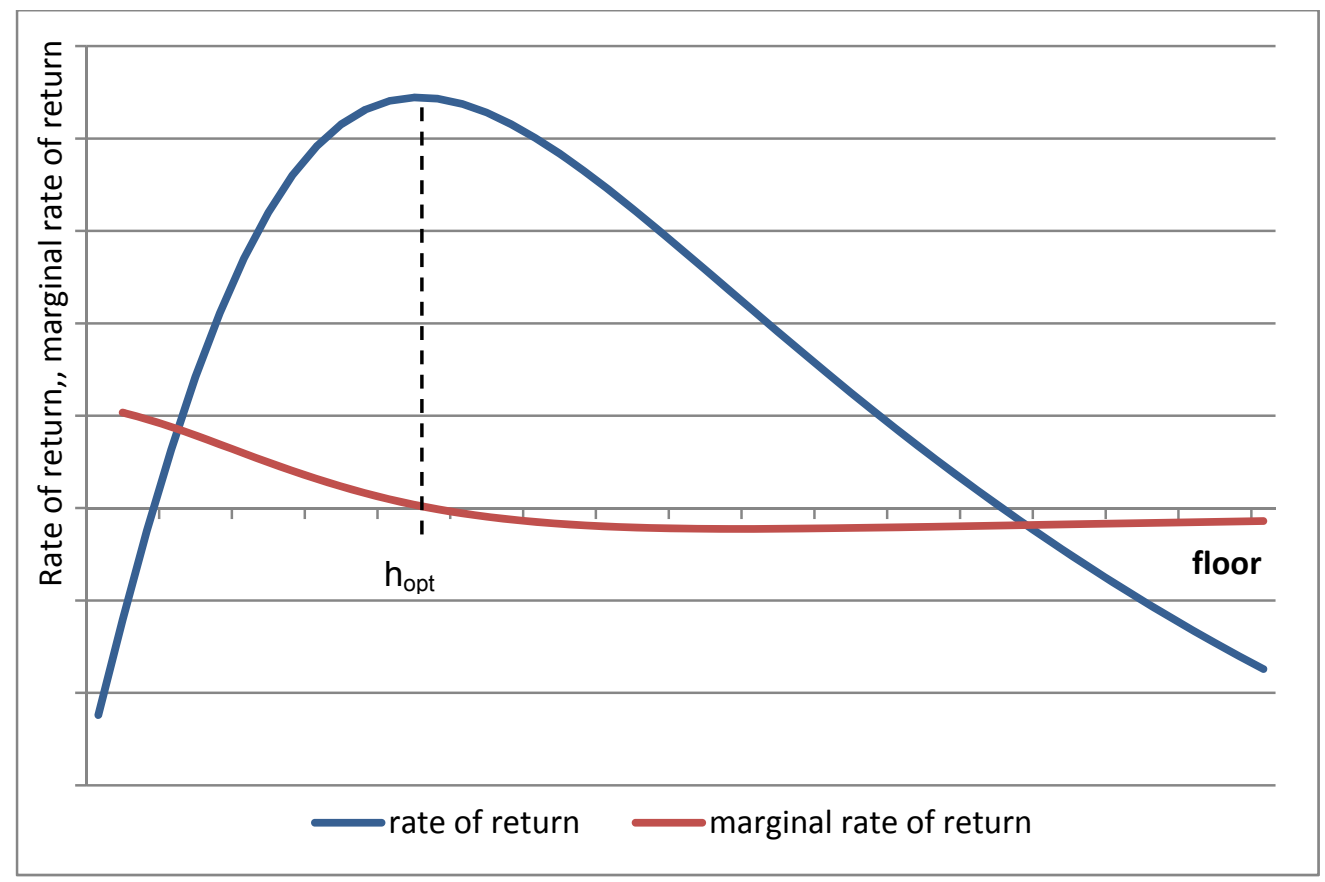

Fig. 6. Development height maximizing rate of return on investment. Source: developed by the author.

When comparing optimal building heights derived from the two measures of investment effectiveness (profit and rate of return), one needs to remember that because the cost of the development and the income it can generate are related to each other, the rate of return indicates the optimum height earlier than maximum profit does. In other words, a building height obtained by maximizing the rate of return will be lower than one established by maximizing the profit $-\mathrm{h}_{R R}<\mathrm{h}_{\text {profit }}$ (Fig. 7).

The analysis of the decision-making process performed by a developer seeking the optimum height a landed property development has been simplified. As observed by J. Berger, in business practice a developer would consider a range of development options with buildings differing in area and height (Berger, 1967). The optimal height of a building with a certain base area does not necessarily apply to all of the available options.

Another simplification is that the aspect of project financing has been left out. As land property development is a capital-intensive activity, large amounts of the necessary funding must be acquired from external sources. The availability and cost of capital may, in many cases, have a major effect on the scale of the projected development, including the height of the building.

\section{Conclusions}

In the development business, the height of the projected buildings is one of the main elements of decision-making. Building height is determined by many factors, e.g. technical, spatial, economic and financial. The main economic factors stimulating the expansion of high-rise development include the 
rising demand for commercial and residential space in present-day cities, the shortage of attractively located urban land within city limits and high prices of such land.

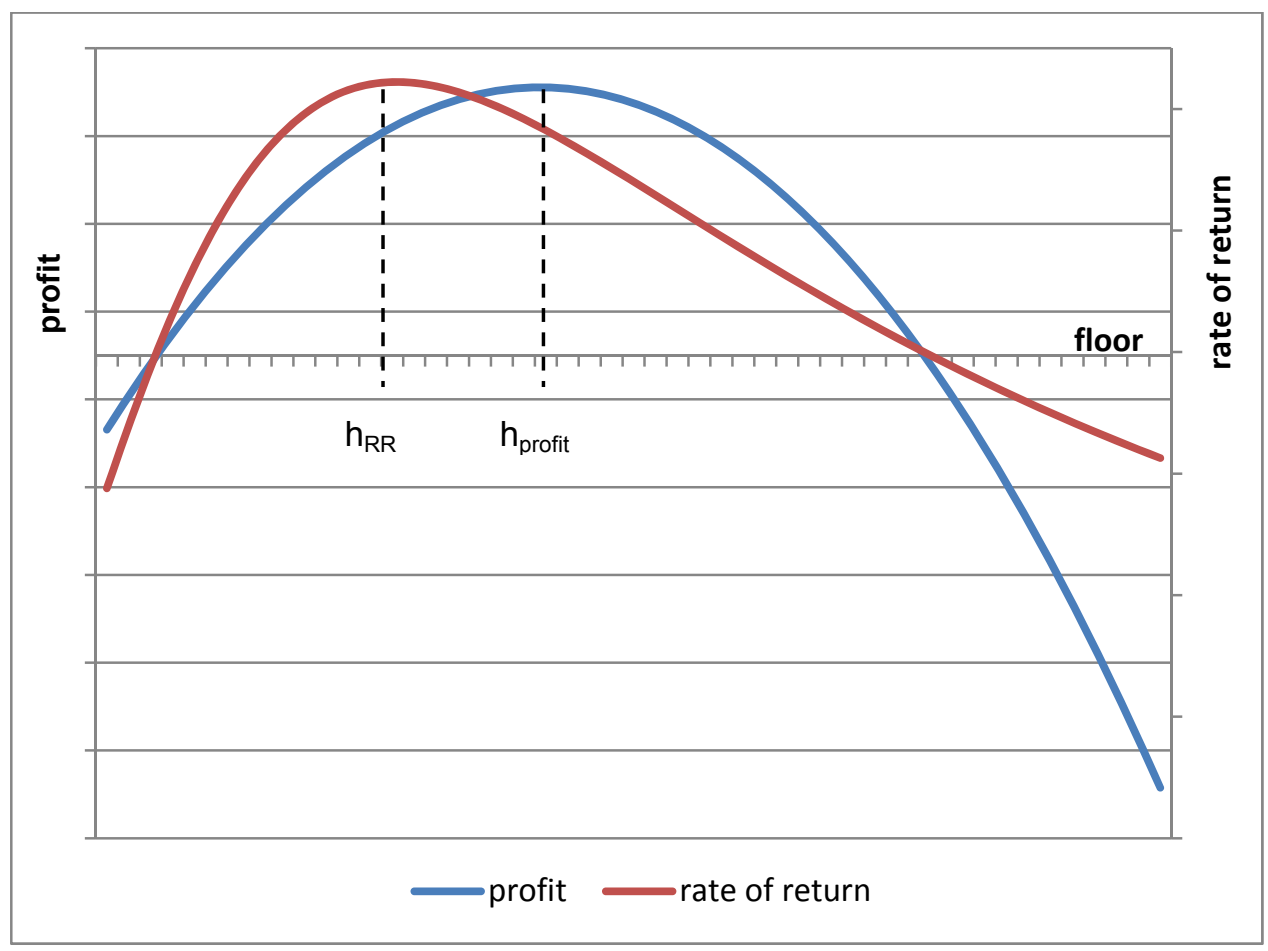

Fig. 7. Optimal building height by measure of investment profitability. Source: developed by the author.

Developers seeking to establish the optimal height of development can assess project profitability using different criteria (maximization of profits or rate of return), with their choice having a major effect on which height variant they will find the most effective.

\section{References:}

Ali M. M., Al-Kodmany K., 2012, Tall Buildings and Urban Habitat of the 21st Century: A Global Perspective, Buildings Journal, Spatial Issue, Vol. 2, No. 4.

BERGER J., 1967, Determination of the Economic Height of High-Rise Buildings, University of California, Los Angeles.

ButLer D., SIEBRITS J., 2012, Towers and the Height Premium in London, CBRE.

CELKA K., 2012, Preferencje najemców na rynku nieruchomości biurowych (The preferences of tenants at office market), Studies and Materials of the Polish Real Estate Scientific Society (Towarzystwo Naukowe Nieruchomości), scientific editor: S. Źróbek, Vol. 20 No. 2, Olsztyn, pp. 259-266.

Chau, K.W., Wong S.K., Yau Y, Cheung A.K.C., 2007, Determining Optimal Building Height, Urban Studies Vol. 44 No. 3.

Clark W. C., Kingston J. L., 1930, The Skyscraper. A Study in the Economic Height of Modern Office Buildings, American Institute of Steel Construction INC, New York.

DE JONG P., VAN Oss S., 2007, High Rise Costs, Working Paper, Delft University of Technology.

FArouK A., 2011, High Rise Buildings and How They Affect Countries Progression, Conference Paper, CASA E-LEADER, Croatia.

KNIGHT FRANK RESEARCH, 2007, Tall Buildings Market Analysis.

KUCHARSKA-STASIAK E., 2006, Nieruchomość w gospodarce rynkowej (Real Estate in a Market Economy), PWN, Warszawa.

LANGDon D., WatTS, S., 2002, Cost [in:] Tall Buildings: A Strategic Design Guide, red. Strelitz Z., London: RIBA Pub.

Rozporządzenie Ministra Infrastruktury z dnia 12 kwietnia 2002 roku w sprawie warunków technicznych, jakim powinny odpowiadać budynki i ich usytuowanie Dz. U. 2002 nr 75, poz. 690 z późn. 
$z m$. (Regulation of the Ministry of Infrastructure from 12th April 2002 On the Technical Conditions to be Met by Buildings and Their Location, Journal of Laws, 2002, No. 75, item 690 with amendments).

SerAj S. M., SERAJ T. M., 1995, Problems and Prospects of Tall Buildings in Developing Countries, [in:] Habitat and the High-Rise: Tradition and Innovation, Proceedings of the Fifth World Congress of the Tall Buildings and Urban Habitat held in Amsterdam.

STACHURA E., 2012, Kształtowanie architektury domów i mieszkań z wykorzystaniem wyników badań preferencji mieszkaniowych Polaków (Architectural Design of Houses and Flats According to the Results of Research on Consumer's Housing Preferences), Studies and Materials of the Polish Real Estate Scientific Society (Towarzystwo Naukowe Nieruchomości), scientific editor: S. Źróbek, Vol. 20 No. 3, Olsztyn, pp. 55-67. 